\title{
Meta-analytical methods for estimating outcomes from overall response rate in patients with relapsed/refractory diffuse large B-cell lymphoma
}

\author{
Ling Wang ${ }^{1,3}$, Hung Lam², Yaping Shou ${ }^{1,4}$ and Aaron Galaznik ${ }^{1,5}$ \\ ${ }^{1}$ Millennium Pharmaceuticals, Inc., a wholly owned subsidiary of Takeda Pharmaceutical Company Limited, Cambridge, MA, \\ USA \\ ${ }^{2}$ MMS Holdings Inc., Canton, MI, USA \\ ${ }^{3}$ Currently employed at Pfizer, Inc. \\ ${ }^{4}$ Currently employed at Trillium Therapeutics Inc. \\ ${ }^{5}$ Currently employed at SHYFT Analytics, a Medidata Company \\ Correspondence to: Aaron Galaznik, email: aaron.galaznik.wg04@wharton.upenn.edu
}

Keywords: diffuse large B-cell lymphoma; meta-analyses; outcomes; overall response rate; durable response rate

Received: August 24, $2018 \quad$ Accepted: April 14, $2019 \quad$ Published: May 14, 2019

Copyright: Wang et al. This is an open-access article distributed under the terms of the Creative Commons Attribution License 3.0 (CC BY 3.0), which permits unrestricted use, distribution, and reproduction in any medium, provided the original author and source are credited.

\section{ABSTRACT}

Relapsed/refractory diffuse large B-cell Iymphoma (DLBCL) is highly heterogeneous and current trials are investigating new approaches to improve outcomes. Limited data on response endpoints can confound estimation of a treatment effect when designing studies of novel agents in this setting, which can hinder study sample size calculations, especially if a net estimate is required for a 'physician's choice' comparator arm. Here we estimate complete response rate (CRR), overall response rate (ORR), and extrapolate durable response rates (DRR; CR/partial response lasting $\geq 16$ weeks) for such a comparator arm from published ORRs in DLBCL.

CRR, ORR, and DRR (if reported) were obtained from published clinical trials for approved single-agent therapies in patients with relapsed/refractory aggressive non-Hodgkin lymphoma after $\geq 2$ prior therapies. Meta-analyses were performed to estimate CRR, ORR, and DRR based on ORR data reported from these studies.

Published data from studies of eight monotherapies were included. Meta-analyses using fixed and random effects models showed a pooled estimate for a CRR of $12 \%$ (95\% confidence interval [CI]: 9-15) and $11 \%$ (95\% CI: 8-15), respectively, an ORR of 30\% (95\% CI: $25-35)$ and 30\% (95\% CI: 24-36), respectively, and a DRR of $14 \%$ (95\% CI: 11-18; same for fixed and random effects models). Bayesian meta-analysis estimated a pooled DRR of $14 \%$ (95\% credible interval: 11-19).

CRR estimates for a physician's choice comparator arm in patients with relapsed/ refractory DLBCL were 11-12\%; DRR estimates were $14 \%$ regardless of methodology. Lack of consistency in reported data and choice of endpoints can be addressed using meta-analytic approaches.

\section{INTRODUCTION}

Diffuse large B-cell lymphoma (DLBCL) is an aggressive form of non-Hodgkin lymphoma (NHL) representing approximately $30 \%$ of all NHLs, making it the most common subtype [1-3]. The current standard of care for frontline treatment of DLBCL is rituximab in combination with cyclophosphamide, doxorubicin, vincristine, and prednisone (R-CHOP) [3, 4]. Compared with regimens not containing rituximab, $\mathrm{R}-\mathrm{CHOP}$ offers 
potentially curative therapy with significant survival benefits [5-7]; however, a substantial proportion of patients have disease that either is refractory to or relapses after initial therapy $[3,4,8]$. Patients who relapse following initial treatment but remain chemosensitive are typically treated with high-dose chemotherapy followed by autologous stem cell transplantation (ASCT) [9-11]. For those who do not respond to salvage regimens or have poor outcomes post-ASCT, there is an unmet need for treatment of third-line relapsed or refractory $(R / R)$ DLBCL, as currently there are no approved drugs and no standard of care in this setting $[8,12,13]$.

The $R / R$ DLBCL treatment landscape is rapidly evolving, with multiple new treatments currently under investigation. Novel agents or regimens need to be investigated in the context of this complex clinical landscape, with clinically relevant endpoints required to demonstrate superiority against existing agents. In $\mathrm{R} / \mathrm{R}$ DLBCL, the published data on response endpoints are limited, and there is a lack of consistency in the data reported and the choice of efficacy endpoints in singleagent studies. This makes it difficult to estimate standardof-care response rates and can confound estimation of a threshold or comparator rate treatment effect when designing studies of novel agents in this setting. In turn, this hinders study sample size calculations, which are needed to inform clinical trial design.

Overall response rate (ORR) or complete response rate (CRR) has been widely used as the primary endpoint in studies in R/R DLBCL. However, durable response rate (DRR), defined as the percentage of patients with a time interval of $\geq 16$ weeks from first $C R$ or partial response (PR) to progression of disease or death, may be a more clinically relevant endpoint as it captures both the proportion of patients achieving a response and the duration of these responses in a single endpoint. Furthermore, the US Food and Drug Administration guidance for Approval of Cancer Drugs and Biologics indicates the importance of durability of clinical response for assessing clinical benefit in oncology therapies, particularly when overall survival (OS) data are not yet available $[14,15]$. However, to date, the only reported use of DRR in DLBCL was in the EXTEND study of pixantrone versus single-agent chemotherapies, in which $17.1 \%$ of pixantrone-treated patients achieved a DRR [16]. In a limited study of vorinostat in R/R DLBCL, the single responder among the 18 enrolled patients had a durable response lasting for at least 4 months, equating to a DRR of $6 \%$ [17].

The purpose of this paper is to illustrate a methodological approach for addressing this gap in available response durability data in R/R DLBCL. Starting with a targeted literature review, we used meta-analytic approaches to estimate CRR and ORR as well as to extrapolate DRR from reported ORR data for a physician's choice comparator arm of single-agent therapy against which to compare a novel agent. Results can be used to inform the design of future clinical trials in this setting.

\section{RESULTS}

\section{Selection of studies}

Following our targeted literature review, we identified 10 studies of eight monotherapies that were eligible for inclusion in the present analyses [16-25]. ORR was reported in eight studies and DRR was reported in two studies. The key patient characteristics, study details, and response rates reported in these studies are summarized in Table 1.

\section{Frequentist meta-analysis}

Fixed and random effect analyses were conducted using standard meta-analysis practice, including calculation and application of weights for each study [26]. Metaanalysis using fixed effects and random effects modelling showed pooled estimates of CRR of $12 \%$ (95\% CI: 9-15) and 11\% (95\% CI: 8-15), respectively (Table 2; Figure 1), and estimates of ORR of 30\% (95\% CI: 25-35) and 30\% (95\% CI: 24-36), respectively (Table 2; Figure 2).

Using data from studies of pixantrone and vorinostat $[16,17]$ and assuming a simple relationship between ORR and DRR of DRR $=r^{*}$ ORR, the correlation coefficient was estimated to be $r=0.4696$. This relationship was used to estimate DRR in the studies of the other six agents. Estimated DRR was 14\% (95\% CI: 11-18) modelled with both fixed effects and random effects (Table 2; Figure 3).

\section{Bayesian meta-analysis}

A separate Bayesian meta-analysis was performed using published results of ORR and DRR for the eight monotherapies. Posterior distribution of the ratio between ORR and DRR was estimated using data from studies of pixantrone and vorinostat $[16,17]$. DRRs for the other six monotherapies were then estimated. Estimated value for r was 0.4758 (95\% CI: 0.2391-0.8119). Bayesian metaanalysis estimated the pooled DRR, assuming a normal distribution for the log odds of DRR, to be $14.43 \%$ (95\% CI: 10.53-18.7) (Table 2; Figure 4). The Bayesian estimate of the pooled DRR was very similar to results from the frequentist meta-analysis approach using both fixed and random effects models.

\section{DISCUSSION}

Estimating effect size is a crucial aspect of sample size calculation for any clinical trial. For trials comparing to the standard of care, whether in the form of a comparator arm or a historic benchmark, this is challenging when the standard-of-care treatment options 
Table 1: Studies of single-agent therapies identified in our targeted literature review and the reported data on ORR, CRR, and DRR

\begin{tabular}{|c|c|c|c|c|c|c|c|}
\hline Regimen & Patients, $n$ & $\begin{array}{l}\text { Median age, } \\
\text { years (range) }\end{array}$ & Study design & $\begin{array}{c}\text { Median } \\
\text { number } \\
\text { of prior } \\
\text { therapies } \\
\end{array}$ & ORR (\%) & CR (\%) & $\begin{array}{l}\text { Reported } \\
\text { DRR (\%) }\end{array}$ \\
\hline Rituximab [18] & 54 & $\begin{array}{c}62.5(20-83) \\
\text { Group A } \\
65(32-86) \\
\text { Group B }\end{array}$ & $\begin{array}{c}\text { Phase II, open- } \\
\text { label, } \\
\text { randomized }\end{array}$ & NR & 31 & 9 & - \\
\hline $\begin{array}{l}\text { Gemcitabine } \\
{[20]}\end{array}$ & 30 & 61 & Phase II & 2 & 20 & 0 & - \\
\hline $\begin{array}{l}\text { Bendamustine } \\
{[22]}\end{array}$ & 18 & $66(38-84)$ & Phase II & 2 & 44 & 17 & - \\
\hline $\begin{array}{l}\text { Oxaliplatin } \\
\text { [21] }\end{array}$ & $22^{\mathrm{a}}$ & $62(28-79)^{\mathrm{b}}$ & Phase II & $2^{\mathrm{b}}$ & $32^{\mathrm{a}}$ & $9^{\mathrm{a}}$ & - \\
\hline Vorinostat [17] & 18 & $66.5(59-86)$ & Phase II & 2 & 6 & 6 & 6 \\
\hline Pixantrone [16] & $70^{c}$ & $60(18-80)$ & $\begin{array}{l}\text { Phase III, } \\
\text { open-label, } \\
\text { randomized }\end{array}$ & 3 & 37 & 20 & 17 \\
\hline Ibrutinib [24] & 80 & $\begin{array}{c}60(34-89) \text { ABC } \\
65 \text { (28-92) GCB } \\
63 \text { (44-85) } \\
\text { Unclassified } \\
65(58-78) \\
\text { Unknown }\end{array}$ & Phase I/II & $\begin{array}{c}3^{\mathrm{d}} \\
3.5^{\mathrm{f}}\end{array}$ & $25^{\mathrm{e}}$ & 10 & - \\
\hline $\begin{array}{l}\text { Lenalidomide } \\
\text { [19] (for DRR } \\
\text { estimation) }\end{array}$ & $51^{g}$ & $69(28-84)$ & $\begin{array}{l}\text { Phase II/III, } \\
\text { open-label, } \\
\text { randomized }\end{array}$ & 2 & 28 & 10 & - \\
\hline $\begin{array}{l}\text { Lenalidomide } \\
\text { [23] (for CRR } \\
\text { estimation) }\end{array}$ & $\begin{array}{c}49 \\
(n=26 \text { for } \\
\text { DLBCL only) }\end{array}$ & $65(23-86)$ & Phase II & 4 & $\begin{array}{l}35 \text { (19 for } \\
\text { DLBCL) }\end{array}$ & $\begin{array}{c}12 \\
(12 \text { for } \\
\text { DLBCL) }\end{array}$ & - \\
\hline $\begin{array}{l}\text { Lenalidomide } \\
\text { [25] (for CRR } \\
\text { estimation) }\end{array}$ & $\begin{array}{c}217 \\
(n=108 \text { for } \\
\text { DLBCL) }\end{array}$ & $66(21-87)$ & Phase II & 3 & $\begin{array}{l}35 \text { (28 for } \\
\text { DLBCL) }\end{array}$ & $\begin{array}{l}13 \text { ( } 7 \text { for } \\
\text { DLBCL) }\end{array}$ & - \\
\hline
\end{tabular}

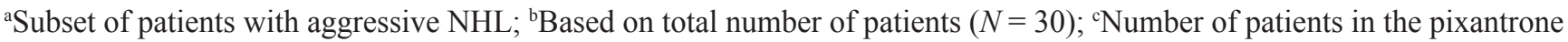
arm (total study $N=140$ ); ${ }^{\mathrm{d} B a s e d}$ on patients classified as $\mathrm{ABC}$, unclassified, and unknown; ${ }^{\mathrm{e}} \mathrm{ORR}=37 \%$ in a subset of patients with activated B-Cell DLBCL; ${ }^{\mathrm{f} B a s e d}$ on patients classified as GCB; ${ }^{\circ}$ Number of patients in the lenalidomide arm (total study $N=102$ ).

Abbreviations: $\mathrm{ABC}$, activated $\mathrm{B}$ cell-like; $\mathrm{CR}$, complete response; $\mathrm{CRR}$, complete response rate; $\mathrm{DLBCL}$, diffuse large B-cell lymphoma; DRR, durable response rate; GCB, germinal center B cell-like; NR, not reported; ORR, overall response rate.

are highly fragmented and rapidly evolving. In DLBCL, treatment guidelines include many potential regimens for second-line and subsequent therapy $[3,27,28]$ and realworld treatment patterns are heterogeneous [29]. However, there is no established standard of care for third-line or later therapy in DLBCL. Furthermore, published studies may not include all endpoints of interest, as seen for DRR in R/R DLBCL. These trends make estimation of effect size, especially in a comparator population receiving a variety of treatments, difficult to assess.
Here we outline a meta-analytical process both for estimation of anticipated standard-of-care response rates in terms of ORR and CRR, as well as for extrapolation to anticipated DRR when information for this endpoint is not available. This methodology provides a quantitative approach to extrapolation using multiple sources. In addition to providing estimates, it also allows for a statistically rigorous approach to quantifying the uncertainty around those estimates. Furthermore, this approach can be implemented quickly, using publicly 
Table 2: Pooled and individual estimated CRRs (frequentist meta-analysis), ORRs (frequentist meta-analysis), and DRRs (frequentist and Bayesian meta-analysis) for the included studies

\begin{tabular}{|c|c|c|c|c|}
\hline \multirow{2}{*}{ Regimen } & \multicolumn{3}{|c|}{ Frequentist meta-analysis } & \multirow{2}{*}{$\begin{array}{c}\text { Bayesian meta- } \\
\text { analysis }\end{array}$} \\
\hline & CRR (95\% CI) & ORR (95\% CI) & DRR (95\% CI) & \\
\hline Rituximab [18] & $0.09(0.03-0.20)$ & $0.31(0.20-0.46)$ & $0.15(0.07-0.27)$ & 0.161 \\
\hline Gemcitabine [20] & $0.00(0.00-0.12)$ & $0.20(0.08-0.39)$ & $0.10(0.02-0.27)$ & 0.1092 \\
\hline Bendamustine [22] & $0.17(0.04-0.41)$ & $0.44(0.22-0.69)$ & $0.22(0.06-0.48)$ & 0.2249 \\
\hline Oxaliplatin [21] & $0.09(0.01-0.29)$ & $0.32(0.14-0.55)$ & $0.14(0.03-0.35)$ & 0.1666 \\
\hline Vorinostat [17] & $0.06(0.00-0.27)$ & $0.06(0.00-0.27)$ & $0.06(0.00-0.27)$ & 0.04996 \\
\hline Pixantrone [16] & $0.20(0.11-0.31)$ & $0.37(0.26-0.50)$ & $0.17(0.09-0.28)$ & 0.1874 \\
\hline Ibrutinib [24] & $0.10(0.04-0.19)$ & $0.25(0.16-0.36)$ & $0.11(0.05-0.20)$ & 0.1279 \\
\hline Lenalidomide & $\begin{array}{l}0.12(0.02-0.30)[23] \\
0.07(0.03-0.14)[25]\end{array}$ & $0.27(0.16-0.42)$ [19] & $0.14(0.06-0.26)[19]$ & 0.1413 \\
\hline Pooled results & $\begin{array}{l}\text { Fixed: } 0.12(0.09-0.15) \\
\text { Random: } 0.11(0.08-0.15)\end{array}$ & $\begin{array}{l}\text { Fixed: } 0.30(0.25-0.35) \\
\text { Random: } 0.30(0.24-0.36)\end{array}$ & $\begin{array}{l}\text { Fixed: } 0.14(0.11-0.18) \\
\text { Random: } 0.14(0.11-0.18)\end{array}$ & $0.1443(0.1053-0.1873)$ \\
\hline
\end{tabular}

Abbreviations: CI, confidence interval; CRR, complete response rate; DRR, durable response rate; ORR, overall response rate.

available clinical trial results. Given the known challenges with sharing of clinical trial data, particularly across multiple sponsors, this enables faster generation of estimates for clinical study planning [30].

In this study, two frequentist and one Bayesian metaanalysis methods were used to estimate response rates and extrapolate DRRs based on published ORRs from various studies investigating single-agent regimens in patients with R/R DLBCL. In frequentist meta-analysis using fixed and random effects modelling, pooled estimates of CRR were $12 \%$ and $11 \%$ and pooled estimates of ORR were $30 \%$ and $30 \%$, respectively. The pooled DRR estimates were very similar across analyses, with an estimated pooled DRR of $14 \%$ using fixed effects and random effects modelling, and 14.4\% predicted using Bayesian meta-analysis. The consistency of the predicted DRRs across different methods demonstrates the robustness of the final estimate.

The benefit of calculating these estimates is twofold. First, by estimating the likely CRR and ORR rates and ranges for different agents, one can quantitatively estimate the likelihood of different effect sizes of a new therapeutic against different potential comparators. This can thereby inform sample size decisions in the backdrop of a desired power to detect a given magnitude of effect [31]. Second, for this particular example, this approach allows extrapolation of potential DRR rates and quantifying the uncertainty around

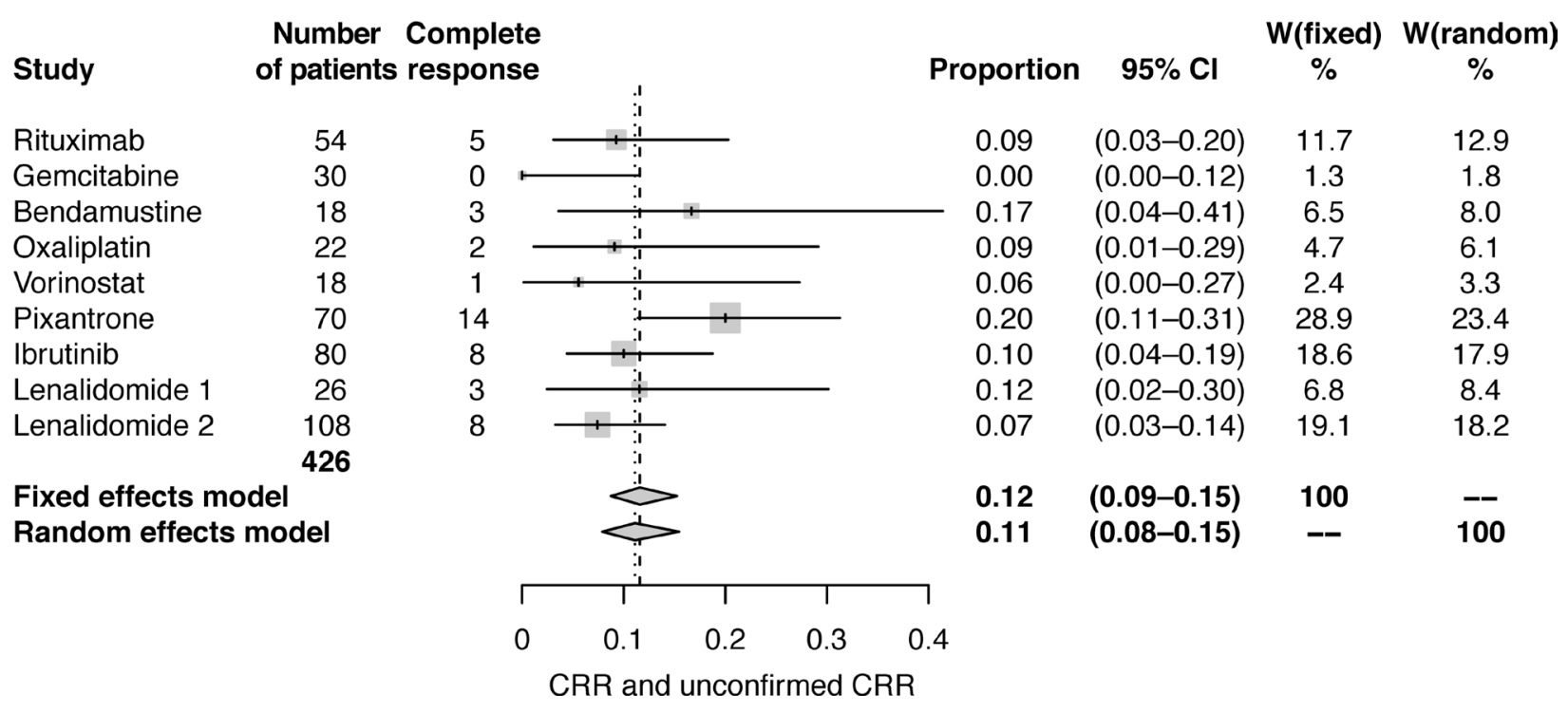

Figure 1: Forest plot of frequentist meta-analysis estimated CRRs. Columns W(fixed) and W(random) are the weights used in the fixed effect and random effect models [26]. 


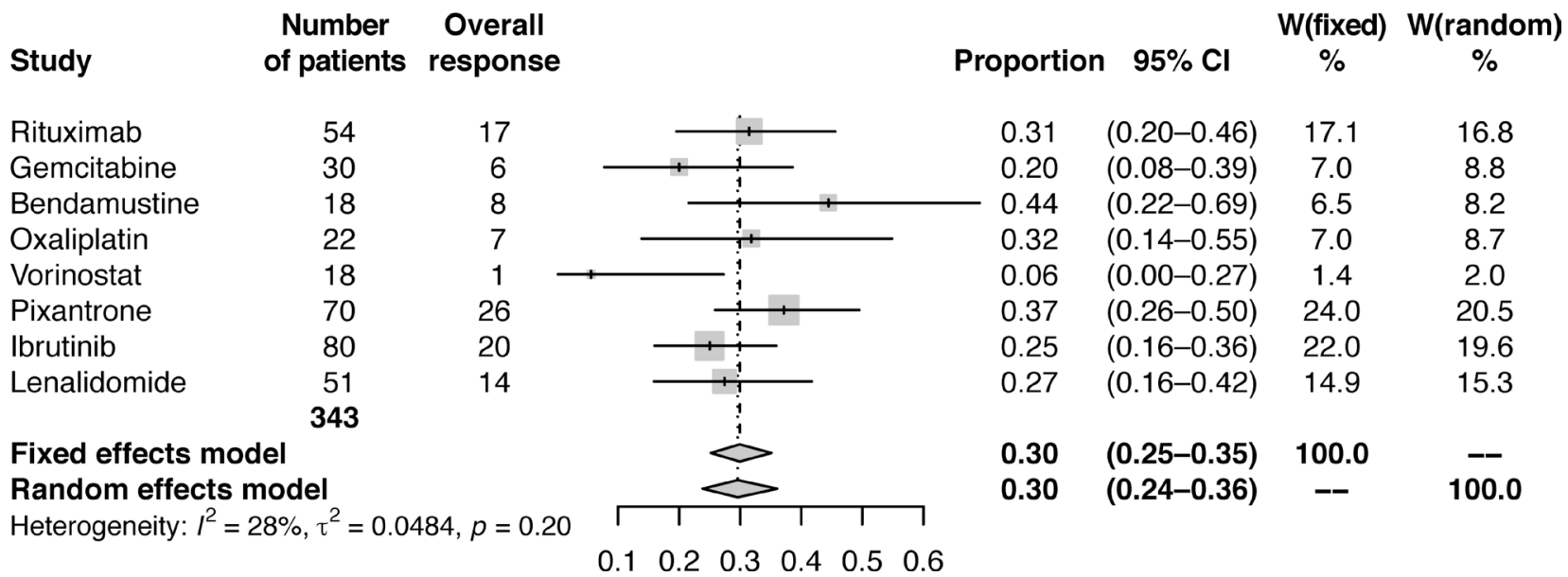

Figure 2: Forest plot of frequentist meta-analysis estimated ORRs. Columns W(fixed) and W(random) are the weights used in the fixed effect and random effect models [26].

\begin{tabular}{|c|c|c|c|c|c|c|c|c|c|c|}
\hline Study & $\begin{array}{c}\text { Number } \\
\text { of patients }\end{array}$ & $\begin{array}{l}\text { Durable } \\
\text { response }\end{array}$ & & & & & DRR & $95 \% \mathrm{Cl}$ & $\begin{array}{c}W(\text { fixed) } \\
\%\end{array}$ & $\begin{array}{c}\text { W(random) } \\
\%\end{array}$ \\
\hline Rituximab & 54 & 8 & $i$ & 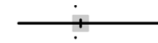 & & & 0.15 & $(0.07-0.27)$ & 17.0 & 17.0 \\
\hline Gemcitabine & 30 & 3 & 1. & & & & 0.10 & $(0.02-0.27)$ & 6.7 & 6.7 \\
\hline Bendamustine & 18 & 4 & 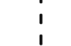 & 7 & & & 0.22 & $(0.06-0.48)$ & 7.8 & 7.8 \\
\hline Oxaliplatin & 22 & 3 & $1-$ & 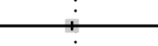 & & & 0.14 & $(0.03-0.35)$ & 6.5 & 6.5 \\
\hline Vorinostat & 18 & 1 & 1 & & & & 0.06 & $(0.00-0.27)$ & 2.4 & 2.4 \\
\hline Pixantrone & 70 & 12 & 1 & + & & & 0.17 & $(0.09-0.28)$ & 24.8 & 24.8 \\
\hline Ibrutinib & 80 & 9 & 1 & $\longrightarrow$ & & & 0.11 & $(0.05-0.20)$ & 19.9 & 19.9 \\
\hline \multirow[t]{2}{*}{ Lenalidomide } & 51 & 7 & 1 & 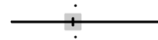 & & & 0.14 & $(0.06-0.26)$ & 15.0 & 15.0 \\
\hline & 343 & & 1 & & & & & & & \\
\hline \multirow{4}{*}{\multicolumn{2}{|c|}{$\begin{array}{l}\text { Fixed effects model } \\
\text { Random effects model }\end{array}$}} & & 1 & $<$ & & & 0.14 & $(0.11-0.18)$ & 100 & - \\
\hline & & & $i$ & $\phi$ & & & 0.14 & $(0.11-0.18)$ & -- & 100 \\
\hline & & & & $\begin{array}{l}1 \\
1\end{array}$ & $T$ & ᄀ & & & & \\
\hline & & & 0.0 & $0.1 \quad 0.2$ & 0.3 & 0.4 & & & & \\
\hline
\end{tabular}

Figure 3: Forest plot of frequentist meta-analysis estimated DRRs. Columns W(fixed) and W(random) are the weights used in the fixed effect and random effect models [26].

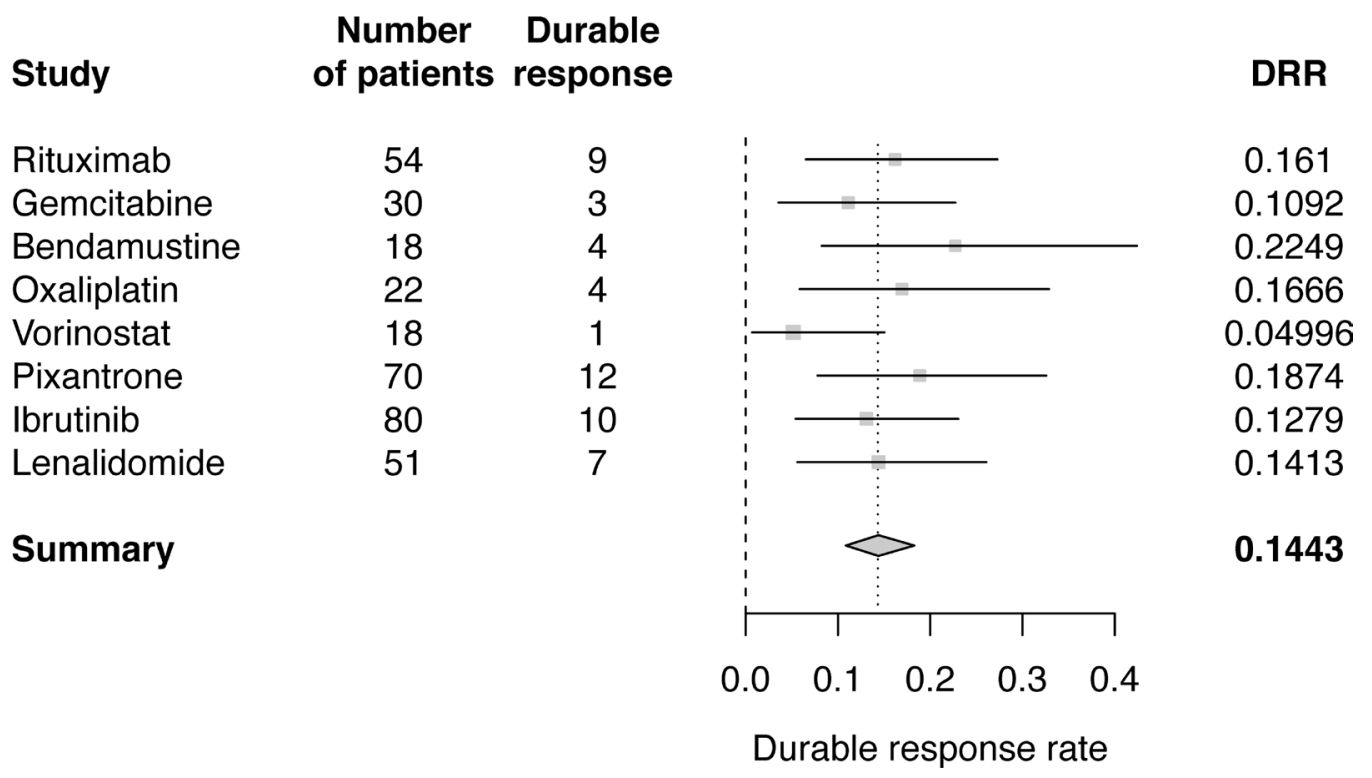

Figure 4: Forest plot of Bayesian meta-analysis estimated DRRs. 
them, which is important given the paucity of available information for this measure.

The largest limitation of the present meta-analysis is the assumption made for the extrapolation of DRR from ORR, as this is based on data reported from only two studies. Furthermore, there is heterogeneity between the studies in terms of patient characteristics, study designs, and patient numbers. In addition, the studies included in this meta-analysis were restricted to those of monotherapies only; however, combination regimens are also commonplace in the R/R DLBCL setting.

Future enhancements to the current analysis would include use of a systematic literature review approach for study identification, following Cochrane or Centre for Reviews and Dissemination York guidelines, as well as expansion to include combination regimens. Given the lack of treatment guidelines for later-line DLBCL, regimen selection could be done in consultation with clinical oncology experts. Other endpoints, such as progressionfree survival (PFS) or OS could also be evaluated.

The approach outlined in this study also illustrates how meta-analytical techniques may be used to overcome common issues with estimating an effect size for a threshold efficacy target or for a physician's choice comparator arm in studies of patients with R/R DLBCL, including inconsistent types of data reported and choice of endpoints. These data can be used to inform efficacy targets (DRR, ORR, or CRR) as well as sample size calculations in future clinical trials investigating new treatments in R/R DLBCL. Consequently, meta-analytical techniques should be considered when estimating standard-of-care treatment effects in other disease areas similarly characterized by fragmented, evolving treatment landscapes and inconsistent capture of desired endpoints.

\section{MATERIALS AND METHODS}

\section{Targeted literature review}

We conducted a targeted literature review of PubMed from December 1998 to December 2016 to capture publications including and subsequent to earlyphase studies of rituximab and gemcitabine [18, 20]. Search parameters included terms pertaining to aggressive NHLs and assessment of efficacy (ORR, CRR, DRR). Studies of monotherapies were included if they reported efficacy results (at least ORR and CRR) in a R/R ( $\geq 2$ prior lines of therapy) DLBCL population. Studies of combination regimens or not reporting efficacy results specific to a DLBCL population were excluded.

\section{Data collection and statistical analysis}

CRR, ORR, and DRR (where reported) for patients with R/R DLBCL were obtained from selected studies. Two meta-analytical approaches were used to estimate response rates and extrapolate DRR from the reported data. A frequentist meta-analysis approach used fixed effects and random effects meta-analysis models to obtain an overall estimate of response from the data reported on existing DLBCL treatments. The ORR and DRR reported for the existing treatments for DLBCL (Table 1) showed a relationship between ORR and DRR for vorinostat and pixantrone. Data from these two drugs were used to estimate the relationship between ORR and DRR. The ranges of distribution for both ORR and DRR were between 0 and 1, and all durable responses were responses such that $\mathrm{DRR} \leq \mathrm{ORR}$. Therefore, it was reasonable to assume that $\mathrm{DRR}=\mathrm{r}^{*} \mathrm{ORR}$, where $0<\mathrm{r} \leq 1$. A least squares approach using data from vorinostat and pixantrone studies was used to estimate $r$, which was then used to estimate DRR in other studies. The number of durable responders was then calculated using the sample size for each study.

Meta-analysis on the estimated DRRs using fixed and random effects models [32] was used to estimate pooled DRR. A Bayesian meta-analysis [33] was carried out using the published values for ORR and the available values for DRR. The ratio of DRR and ORR was estimated by assuming beta distributions for ORR and DRR, and binomial distributions for the number of responders and number of durable responders: $n_{\text {resp }} \sim \operatorname{binomial}(\mathrm{ORR}, \mathrm{n})$, ORR $\sim \operatorname{Beta}\left(\mathrm{a}_{1}, \mathrm{a}_{2}\right), \mathrm{n}_{\text {duresp }} \sim \operatorname{binomial}(\mathrm{DRR}, \mathrm{n}), \mathrm{DRR} \sim \operatorname{Beta}\left(\mathrm{b}_{1}\right.$, $\left.\mathrm{b}_{2}\right), \mathrm{r}=\mathrm{DRR} / \mathrm{ORR}$, with hyper parameters $\mathrm{a}_{1}, \mathrm{a}_{2}, \mathrm{~b}_{1}, \mathrm{~b}_{2}$ all following inverse gamma distribution $\operatorname{IG}(0.001,0.001)$. The posterior distribution of $r$ was approximated by a Beta distribution given that $0<\mathrm{r} \leq 1$. Using a grid search of the $\operatorname{Beta}(\mathrm{a}, \mathrm{b})$ distribution parameters $\mathrm{a}$ and $\mathrm{b}$, with the search range between 0 and 10 by 0.01 , we found the optimal a and $b$ by minimizing the sum of the square distances of the 2.5th, 50th, 97.5th percentiles between each of the tried Beta distribution and the posterior quantiles of $r$. The Beta distribution identified using this method was Beta (5.06, 5.07). From this, ratio $\operatorname{Beta}(5.06,5.07), \operatorname{ORR} \sim \operatorname{Beta}(1,1)$, $\mathrm{n}_{\text {resp }} \sim \operatorname{binomial}(\mathrm{ORR}, \mathrm{n}), \mathrm{n}_{\text {duresp }}=\mathrm{r}^{*} \mathrm{n} * \mathrm{ORR}$ estimated the number of durable responses for each study. Finally, the meta-analysis was performed by estimating the posterior mean of logit(DRR), which was assumed to be normally distributed: Normal distribution: $\mathrm{n}_{\text {duresp }} \sim \operatorname{binomial}(\mathrm{DRR}$, n), $\operatorname{logit}(\mathrm{DRR}) \sim \operatorname{Normal}(\mu, 1 / \tau)$ with hyperparameters $\mu \sim \operatorname{Normal}(0,1 / 0.0001), \tau \sim \operatorname{InverseGamma}(0.001,0.001)$. Overall DRR for the meta-analysis was calculated by $\mathrm{e}^{\mu /(}\left(1+\mathrm{e}^{\mu}\right)$.

\section{Abbreviations}

ASCT: autologous stem cell transplantation; CR: complete response; CRR: complete response rate; DLBCL: diffuse large B-cell lymphoma; DRR: durable response rate; NHL: non-Hodgkin lymphoma; ORR: overall response rate; OS: overall survival; PFS: progression-free survival; PR: partial response; R/R: 
relapsed/refractory; R-CHOP: rituximab in combination with cyclophosphamide, doxorubicin, vincristine, and prednisone.

\section{Author contributions}

Conception and design: LW, AG. Collection and assembly of data: All authors. Data analysis and interpretation: All authors. Manuscript writing: LW, AG drafted the manuscript; all authors reviewed and revised the manuscript. Final approval of manuscript: All authors.

\section{ACKNOWLEDGMENTS}

The authors would like to acknowledge Kazuhiro Morita (Millennium Pharmaceuticals, Inc., a wholly owned subsidiary of Takeda Pharmaceutical Company Limited) for his assistance with the targeted literature search. The authors would also like to acknowledge writing support from Matthew Hallam (FireKite, an Ashfield company, part of UDG Healthcare plc), which was funded by Millennium Pharmaceuticals, Inc., and complied with Good Publication Practice 3 ethical guidelines (Battisti et al. Ann Intern Med 2015; 163:461-4), and editorial support from Janice Y. Ahn, PhD (Millennium Pharmaceuticals, Inc.).

\section{CONFLICTS OF INTEREST}

LW, YS, AG: Employment (Millennium Pharmaceuticals, Inc., a wholly owned subsidiary of Takeda Pharmaceutical Company Limited); HL: Employment (MMS Holdings Inc. and Millennium Pharmaceuticals, Inc., a wholly owned subsidiary of Takeda Pharmaceutical Company Limited); AG: Stock ownership (Takeda).

\section{FUNDING}

Research supported by Millennium Pharmaceuticals, Inc., a wholly owned subsidiary of Takeda Pharmaceutical Company Limited.

\section{REFERENCES}

1. Cultrera JL, Dalia SM. Diffuse large B-cell lymphoma: current strategies and future directions. Cancer Control. 2012; 19:204-213. https://doi. org/10.1177/107327481201900305. [PubMed]

2. Teras LR, DeSantis CE, Cerhan JR, Morton LM, Jemal A, Flowers CR. 2016 US lymphoid malignancy statistics by World Health Organization subtypes. CA Cancer J Clin. 2016. https://doi.org/10.3322/caac.21357. [PubMed]

3. Tilly H, Gomes da Silva M, Vitolo U, Jack A, Meignan M, Lopez-Guillermo A, Walewski J, Andre M, Johnson
PW, Pfreundschuh M, Ladetto M. Diffuse large B-cell lymphoma (DLBCL): ESMO Clinical Practice Guidelines for diagnosis, treatment and follow-up. Ann Oncol. 2015; 26:v116-125. https://doi.org/10.1093/annonc/mdv304. [PubMed]

4. Sinha R, Nastoupil L, Flowers CR. Treatment Strategies for Patients with Diffuse Large B-Cell Lymphoma: Past, Present, and Future. Blood Lymphat Cancer. 2012; 2012:87-98. $\quad$ https://doi.org/10.2147/BLCTT.S18701. [PubMed]

5. Pfreundschuh M, Trumper L, Osterborg A, Pettengell R, Trneny M, Imrie K, Ma D, Gill D, Walewski J, Zinzani PL, Stahel R, Kvaloy S, Shpilberg O, et al. CHOPlike chemotherapy plus rituximab versus CHOP-like chemotherapy alone in young patients with good-prognosis diffuse large-B-cell lymphoma: a randomised controlled trial by the MabThera International Trial (MInT) Group. Lancet Oncol. 2006; 7:379-391. https://doi.org/10.1016/ S1470-2045(06)70664-7. [PubMed]

6. Coiffier B, Thieblemont C, Van Den Neste E, Lepeu G, Plantier I, Castaigne S, Lefort S, Marit G, Macro M, Sebban C, Belhadj K, Bordessoule D, Ferme C, et al. Longterm outcome of patients in the LNH-98.5 trial, the first randomized study comparing rituximab-CHOP to standard CHOP chemotherapy in DLBCL patients: a study by the Groupe d'Etudes des Lymphomes de l'Adulte. Blood. 2010; 116:2040-2045. https://doi.org/10.1182/blood-2010-03276246. [PubMed]

7. Feugier P, Van Hoof A, Sebban C, Solal-Celigny P, Bouabdallah R, Ferme C, Christian B, Lepage E, Tilly H, Morschhauser F, Gaulard P, Salles G, Bosly A, et al. Long-term results of the R-CHOP study in the treatment of elderly patients with diffuse large B-cell lymphoma: a study by the Groupe d'Etude des Lymphomes de l'Adulte. J Clin Oncol. 2005; 23:4117-4126. https://doi.org/10.1200/ JCO.2005.09.131. [PubMed]

8. Nagle SJ, Woo K, Schuster SJ, Nasta SD, Stadtmauer E, Mick R, Svoboda J. Outcomes of patients with relapsed/ refractory diffuse large B-cell lymphoma with progression of lymphoma after autologous stem cell transplantation in the rituximab era. Am J Hematol. 2013; 88:890-894. https:// doi.org/10.1002/ajh.23524. [PubMed]

9. Gisselbrecht C, Glass B, Mounier N, Singh Gill D, Linch DC, Trneny M, Bosly A, Ketterer N, Shpilberg O, Hagberg $\mathrm{H}$, Ma D, Briere J, Moskowitz CH, et al. Salvage regimens with autologous transplantation for relapsed large B-cell lymphoma in the rituximab era. J Clin Oncol. 2010; 28:4184-4190. https://doi.org/10.1200/JCO.2010.28.1618. [PubMed]

10. Philip T. High dose therapy and ABMT rescue in lymphoma and solid tumours. Eur J Cancer. 1995; 31A:808-809. https://doi.org/10.1016/0959-8049(95)00096-2. [PubMed]

11. Shipp MA, Abeloff MD, Antman KH, Carroll G, Hagenbeek A, Loeffler M, Montserrat E, Radford JA, Salles G, Schmitz N, Symann M, Armitage JO, Philip T, 
et al. International Consensus Conference on High-Dose Therapy with Hematopoietic Stem Cell Transplantation in Aggressive Non-Hodgkin's Lymphomas: report of the jury. J Clin Oncol. 1999; 17:423-429. https://doi.org/10.1200/ JCO.1999.17.1.423. [PubMed]

12. Crump M, Neelapu SS, Farooq U, Van Den Neste E, Kuruvilla J, Westin J, Link BK, Hay A, Cerhan JR, Zhu L, Boussetta S, Feng L, Maurer MJ, et al. Outcomes in refractory diffuse large B-cell lymphoma: results from the international SCHOLAR-1 study. Blood. 2017; 130:1800 1808. https://doi.org/10.1182/blood-2017-03-769620. [PubMed]

13. Van Den Neste E, Schmitz N, Mounier N, Gill D, Linch D, Trneny M, Milpied N, Radford J, Ketterer N, Shpilberg O, Duhrsen U, Ma D, Briere J, et al. Outcome of patients with relapsed diffuse large B-cell lymphoma who fail secondline salvage regimens in the International CORAL study. Bone Marrow Transplant. 2016; 51:51-57. https://doi. org/10.1038/bmt.2015.213. [PubMed]

14. Clinical Trial Endpoints for the Approval of Cancer Drugs and Biologics Guidance for Industry. December 2018. U.S. Department of Health and Human Services Food and Drug Administration. Available from: https://www.fda.gov/ regulatory-information/search-fda-guidance-documents/ clinical-trial-endpoints-approval-cancer-drugs-and-biologics.

15. Pazdur R. Endpoints for assessing drug activity in clinical trials. Oncologist. 2008; 13:19-21. https://doi.org/10.1634/ theoncologist.13-S2-19. [PubMed]

16. Pettengell R, Coiffier B, Narayanan G, de Mendoza FH, Digumarti R, Gomez H, Zinzani PL, Schiller G, Rizzieri D, Boland G, Cernohous P, Wang L, Kuepfer C, et al. Pixantrone dimaleate versus other chemotherapeutic agents as a single-agent salvage treatment in patients with relapsed or refractory aggressive non-Hodgkin lymphoma: a phase 3, multicentre, open-label, randomised trial. Lancet Oncol. 2012; 13:696-706. https://doi.org/10.1016/S14702045(12)70212-7. [PubMed]

17. Crump M, Coiffier B, Jacobsen ED, Sun L, Ricker JL, Xie H, Frankel SR, Randolph SS, Cheson BD. Phase II trial of oral vorinostat (suberoylanilide hydroxamic acid) in relapsed diffuse large-B-cell lymphoma. Ann Oncol. 2008; 19:964-969. https://doi.org/10.1093/annonc/mdn031. [PubMed]

18. Coiffier B, Haioun C, Ketterer N, Engert A, Tilly H, Ma D, Johnson P, Lister A, Feuring-Buske M, Radford JA, Capdeville R, Diehl V, Reyes F. Rituximab (anti-CD20 monoclonal antibody) for the treatment of patients with relapsing or refractory aggressive lymphoma: a multicenter phase II study. Blood. 1998; 92:1927-1932. [PubMed]

19. Czuczman MS, Trneny M, Davies A, Rule S, Linton KM, Wagner-Johnston N, Gascoyne RD, Slack GW, Brousset P, Eberhard DA, Hernandez-Ilizaliturri FJ, Salles G, Witzig TE, et al. A Phase 2/3 Multicenter, Randomized, Open-Label Study to Compare the Efficacy and Safety of
Lenalidomide Versus Investigator's Choice in Patients with Relapsed or Refractory Diffuse Large B-Cell Lymphoma. Clin Cancer Res. 2017; 23:4127-4137. https://doi. org/10.1158/1078-0432.CCR-16-2818. [PubMed]

20. Fossa A, Santoro A, Hiddemann W, Truemper L, Niederle N, Buksmaui S, Bonadonna G, Seeber S, Nowrousian MR. Gemcitabine as a single agent in the treatment of relapsed or refractory aggressive non-Hodgkin's lymphoma. J Clin Oncol. 1999; 17:3786-3792. https://doi.org/10.1200/ JCO.1999.17.12.3786. [PubMed]

21. Oki Y, McLaughlin P, Pro B, Hagemeister FB, Bleyer A, Loyer E, Younes A. Phase II study of oxaliplatin in patients with recurrent or refractory non-Hodgkin lymphoma. Cancer. 2005; 104:781-787. https://doi.org/10.1002/ cncr.21219. [PubMed]

22. Weidmann E, Kim SZ, Rost A, Schuppert H, Seipelt G, Hoelzer D, Mitrou PS. Bendamustine is effective in relapsed or refractory aggressive non-Hodgkin's lymphoma. Ann Oncol. 2002; 13:1285-1289. https://doi.org/10.1093/ annonc/mdf189. [PubMed]

23. Wiernik PH, Lossos IS, Tuscano JM, Justice G, Vose JM, Cole CE, Lam W, McBride K, Wride K, Pietronigro D, Takeshita K, Ervin-Haynes A, Zeldis JB, et al. Lenalidomide monotherapy in relapsed or refractory aggressive nonHodgkin's lymphoma. J Clin Oncol. 2008; 26:4952-4957. https://doi.org/10.1200/JCO.2007.15.3429. [PubMed]

24. Wilson WH, Young RM, Schmitz R, Yang Y, Pittaluga S, Wright G, Lih CJ, Williams PM, Shaffer AL, Gerecitano J, de Vos S, Goy A, Kenkre VP, et al. Targeting B cell receptor signaling with ibrutinib in diffuse large B cell lymphoma. Nat Med. 2015; 21:922-926. https://doi.org/10.1038/ nm.3884. [PubMed]

25. Witzig TE, Vose JM, Zinzani PL, Reeder CB, Buckstein R, Polikoff JA, Bouabdallah R, Haioun C, Tilly H, Guo P, Pietronigro D, Ervin-Haynes AL, Czuczman MS. An international phase II trial of single-agent lenalidomide for relapsed or refractory aggressive B-cell non-Hodgkin's lymphoma. Ann Oncol. 2011; 22:1622-1627. https://doi. org/10.1093/annonc/mdq626. [PubMed]

26. Schwarzer G, Carpenter JR, Rücker G. Meta-Analysis with R. (Springer International Publishing). 2015. https://doi. org/10.1007/978-3-319-21416-0.

27. Chaganti S, Illidge T, Barrington S, McKay P, Linton K, Cwynarski K, McMillan A, Davies A, Stern S, Peggs K. Guidelines for the management of diffuse large B-cell lymphoma. Br J Haematol. 2016; 174:43-56. https://doi. org/10.1111/bjh.14136. [ [ PubMed]

28. Raut LS, Chakrabarti PP. Management of relapsedrefractory diffuse large B cell lymphoma. South Asian J Cancer. 2014; 3:66-70. https://doi.org/10.4103/2278330X.126531. [PubMed]

29. Galaznik A, Bell J, Seal B, Ogbonnaya A, Hennenfent K, Hamilton L, Eaddy M. Evaluation of Treatment Patterns among Patients with Diffuse Large B-Cell 
Lymphoma (DLBCL) [abstract]. ISPOR 22nd Annual International Meeting, Boston. 2017 May [cited 2018 Mar 23]. Available from: https://tools.ispor.org/ ScientificPresentationsDatabase/Presentation/71696?pd $\mathrm{fid}=49433$.

30. Rockhold FW. Data Sharing: Stakeholder Perspectives On Transparency In Clinical Trials. Clinical Informatics News. Accessed January 2019. Available from: http://www. clinicalinformaticsnews.com/2017/08/22/data-sharingstakeholder-perspectives-on-transparency-in-clinical-trials. aspx.
31. Schulz KF, Grimes DA. Sample size calculations in randomised trials: mandatory and mystical. Lancet. 2005; 365:1348-1353. https://doi.org/10.1016/S01406736(05)61034-3. [PubMed]

32. DerSimonian R, Laird N. Meta-analysis in clinical trials. Control Clin Trials. 1986; 7:177-188. https://doi. org/10.1016/0197-2456(86)90046-2. [PubMed]

33. Whitehead A. A Bayesian Approach to Meta-Analysis. Meta-Analysis of controlled clinical trials. Chichester: John Wiley \& Sons, Ltd. 2003; 259-84. 